The ethical issues surrounding orders not to resuscitate are complex and increasingly a matter for legislative acts and judicial decisions. ${ }^{113}$ Furthermore, decisions on resuscitation have implications for resource management. Despite these issues "Do not resuscitate" orders in many British hospitals are used without guidelines and without assessment of their effectiveness in preventing futile cardiopulmonary resuscitation.

This survey indicates that in the absence of local guidelines about decisions on resuscitation many crash calls may be inappropriate. We advocate more discussion of patients' suitability for resuscitation between doctors, nurses, patients, and patients' relatives. We suggest that the most senior available doctor of the admitting team should be responsible for making initial resuscitation decisions, writing these in the medical notes, and communicating them to the ward nurses. Such decisions should follow locally agreed criteria based on knowledge of pre-arrest characteristics in relation to outcome. Patients' suitability for resuscitation should be reviewed on every consultant ward round, taking into account the views of all the staff caring for the patient and, when appropriate, the views of the patient or the patient's relatives, or both.
We thank the nurses and junior doctors at Fazakerley Hospital for filling in the questionnaires, and Dr F J Nye for his comments on the manuscript.

1 Keatinge RM. Exclusion from resuscitation. $f R$ Soc Med 1989;82:402-5.

2 Urburg $M$, Ways C. Survival after cardiopulmonary resuscitation for an in-hospital cardiac arrest. I Fam Pract 1987;25:41-4.

3 Bedell SE, Delbanco TL, Cook EF, Epstein FH. Survival after CPR in the hospital. NEngl f Med 1983:309:569-76.

4 Peatfield RC, Sillett RW, Taylor D, McNicol MW. Survival after cardia arrest in hospital. Lancet 1977;i:1223-5.

5 Asplund $K$, Britton $M$. Do-not-resuscitate orders in Swedish medical wards. f Intern Med 1990;228:139-45.

6 United Kingdom Central Council for Nursing, Midwifery and Health Visiting. Code of professional conduct for the nurse, midwife and health visitor. 2nd ed. London: UKCC, 1984.

Halligan M, Hamel RP. Ethics committee develops supportive care guidelines. Health Progress 1985;66:26-30,60.

8 Gleeson $\mathrm{K}$, Wise S. The do-not-resuscitate order: still too little too late Arch Intern Med 1990;150: 1057-60.

9 Kamer RS, Dieck EM, McClung JA, White PA, Sivak SL. Effect of New York State's do-not-resuscitate legislation on in-hospital cardiopulmonary resuscitation practice. Am f Med 1990;88:108-11.

10 McClung JA, Kamer RS. Implications of New York's do-not-resuscitate law. N Engl f Med 1990;323:270-2.

11 Stolman CJ, Gregory JJ, Dunn D, Levine JL. Evaluation of patient, physician, nurse and family attitudes toward do-not-resuscitate orders. physician, nurse and family a

12 Dent T, Gillard JH, Aarons EJ, Crimlisk H, Smyth-Pigott P. Preregistration $\omega$ house officers in the four Thames regions: I. Survey of education and $\mathrm{\omega}$ workload $B M 7$ 1990; 300:713-6.

13 Wanzer SH, Federman DD, Adelstein SJ, Cassel CK, Cassem EH, Cranford $\infty$ $\mathrm{RE}$, et al. The physician's responsibility toward hopelessly ill patients. $\vec{\sigma}$ A second look. N Englf Med 1989;320:844-9.

(Accepted 3 October 1991)

\title{
Parathyroid hormone related protein and hypercalcaemia in breast cancer
}

\author{
N J Bundred, Wendy A Ratcliffe, Rosemary A Walker, S Coley, J M Morrison, J G Ratcliffe
}

Abstract

Objective-To see whether parathyroid hormone related protein has a humoral role in breast cancer.

Design-Plasma concentrations and tumour expression of parathyroid hormone related protein were determined (by two site immunoradiometric assay and immunohistochemistry respectively) in women with breast cancer and related to the presence of bone metastases and serum calcium concentrations.

Subjects-Plasma concentrations of parathyroid hormone related protein were measured in 57 women with early breast cancer without apparent bone metastases, 28 women with bone metastases, and 13 women with bone metastases and hypercalcaemia. Tissue positivity for parathyroid hormone related protein was determined retrospectively in 106 primary breast tumours from women without apparent bone metastases and 72 tumours from women with bone metastases, 25 of whom subsequently developed hypercalcaemia.

Results-Plasma parathyroid hormone related protein concentrations were detectable. $(>0.23$ pmol/1) in $12(92 \%)$ of the 13 hypercalcaemic patients with bone metastases compared with $10(36 \%)$ of the 28 normocalcaemic patients with bone metastases and five $(9 \%)$ of the 57 normocalcaemic patients without bone metastases. Parathyroid hormone related protein concentrations were significantly higher in hypercalcaemic than normocalcaemic patients with bone metastases. Tumour staining was positive for parathyroid hormone related protein in $22(88 \%)$ of the 25 primary breast cancers from patients with bone metastases who later developed hypercalcaemia compared with $25(53 \%)$ of the 47 from women in this group who remained normocalcaemic and 55 (52\%) of the 106 early breast cancers from women without known metastases.
Conclusion-Tumour derived parathyroid hormone related protein may have an important humoral role in hypercalcaemia associated with metastatic breast cancer.

\section{Introduction}

Hypercalcaemia is a common complication of malignancy. In patients with breast cancer it has traditionally been attributed to skeletal metastases and local osteolysis by tumour derived factors such as interleukin 1 , prostaglandins, and tumour necrosis factor. ${ }^{12} \frac{}{3}$ There is little evidence that these factors cause hypercalcaemia when introduced by injection, and it is $ᄋ$ assumed that their actions are largely paracrine, involving localised destruction of bone. The bio- 9 chemical changes seen in some patients with hypercal- $\mathcal{N}$ caemia and breast cancer are well documented and $D$ include increased renal tubular reabsorption of calcium, a decrease in the renal tubular threshold for $\tilde{N}$ phosphate reabsorption, and increased excretion of N nephrogenous cyclic AMP. ${ }^{34}$ These abnormalities are consistent with the actions of a tumour derived parathyroid hormone-like factor with effects on both $\stackrel{0}{\odot}$ kidney and bone and have led to the hypothesis that the of mechanism of hypercalcaemia in breast cancer is mediated humorally by a parathyroid hormone-like peptide. $^{45}$

Parathyroid hormone related protein is a hypercal- $\frac{}{\mathbb{Q}}$ caemic factor with similar bioactivity to that of para- 응 thyroid hormone. Since its isolation in 1987 from cancer cell lines and a carcinoma of the breast, ${ }^{6}$ strong evidence has accumulated that parathyroid hormonerelated protein is an important humoral mediator ofo cancer associated hypercalcaemia in patients with solid $\stackrel{?}{?}$ tumours, typically squamous carcinoma of lung. ${ }^{78}$

We have investigated the possibility that parathyroid hormone related protein has a humoral role in 
breast cancer by comparing plasma concentrations and tumour expression of parathyroid hormone related protein in patients with different serum calcium concentrations and metastatic status.

\section{Patients and methods}

The following groups of breast cancers were studied by immunohistochemistry for parathyroid hormone related protein: (a) 72 tumours from normocalcaemic women in whom bone was the initial site of metastatic recurrence (a subset of 25 of these patients subsequently developed hypercalcaemia ("corrected" calcium range $2 \cdot 7-3.9 \mathrm{mmol} / \mathrm{l})$ ); and (b) 106 consecutive tumours from normocalcaemic women with early breast cancer and no obvious metastatic disease.

Plasma parathyroid hormone related protein 1-86 was measured by two site immunoradiometric assay in the following groups of women with breast cancer: $(a)$ hypercalcaemic women with bone metastases $(n=13$; corrected calcium range $2 \cdot 69-4 \cdot 07 \mathrm{mmol} / \mathrm{l}) ;(b)$ normocalcaemic women with bone metastases $(n=28)$; and $(c)$ normocalcaemic women with early operable breast cancer without apparent bone metastases $(n=57)$.

Tumour tissue for immunohistochemistry was available from five patients with hypercalcaemia.

\section{IMMUNOHISTOCHEMISTRY}

For immunohistochemistry all tissue samples were fixed in $4 \%$ formaldehyde in saline and routinely processed to paraffin blocks. The primary antiserum was raised in a rabbit to the mid-region sequence of parathyroid hormone related protein (amino acids 37-67); this antiserum cross reacts with both native and synthetic forms of parathyroid hormone related protein but not parathyroid hormone.

After dewaxing of the section non-specific binding sites were blocked with non-immune swine serum diluted 1/5 for 10 minutes. Excess serum was removed and the primary antiserum diluted $1 / 100$ applied for one hour at room temperature. This was followed by application of biotinylated swine antirabbit immunoglobulin antiserum and streptavidin-biotin peroxidase complex (both Dako Ltd, High Wycombe, Buckinghamshire) and washing in TRIS hydrochloride buffer (pH 7.6). Peroxidase was localised with diaminobenzidinehydrogen peroxide and nuclei counterstained with Mayer's haematoxylin.

Controls for immunohistochemistry included omission of the primary antibody and preincubation of the primary antibody with parathyroid hormone related protein $37-67(0.5 \mathrm{~g} / \mathrm{l})$ for 16 hours at $4^{\circ} \mathrm{C}$ Negative controls in which the primary antibody was replaced by non-immune serum were incubated in each batch of slides. A positive control obtained from a squamous carcinoma of lung was also included.

Staining of tumours was assessed by two indepen-

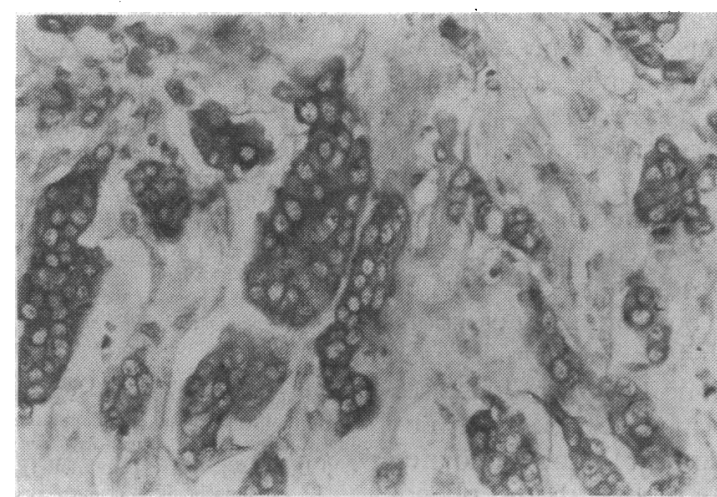

FIG 1-Immunohistochemical localisation of parathyroid hormon related protein in breast cancer tissue from patient with early disease (high power magnification) dent observers who were blind to the identity of the patient and the presence or absence of hypercalcaemia. When interpretation differed further slides were stained until agreement was achieved. Only cytoplasmic reactivity was considered positive.

\section{PLASMA ASSAYS}

Plasma parathyroid hormone related protein 1-86 concentrations were measured by a two site immuno radiometric assay. ${ }^{9}$ Concentrations are undetectable $(\leqslant 0.23 \mathrm{pmol} / \mathrm{l})$ in normocalcaemic controls and detect able in most patients with hypercalcaemia associated with various solid tumours other than breast cancer. Plasma parathyroid hormone 1-84 concentrations (reference range $9-40 \mathrm{ng} / \mathrm{l}$ ) were measured by " $\mathrm{N}$-tact" immunoradiometric assay (INCSTAR, Wokingham, Berkshire)

\section{Results}

Positive cytoplasmic staining for parathyroid hormone related protein was found in $55(52 \%)$ of the 106 early breast cancers (fig 1). The proportion of cellis staining in individual tumours varied, with additionaf variation in intensity, while surrounding stromal tissue was consistently negative. Positive staining was abolished by omission of the primary antiserum and absorption of antiserum by parathyroid hormone related protein 37-67. In the group in whom tumour first recurred in bone positive staining was found in 47 $(65 \%)$ of the 72 primary tumours. Positive immuno staining for parathyroid hormone related proteirf occurred in $22(88 \%)$ primary tumours from the 25 women who developed hypercalcaemia compared with $25(53 \%)$ tumours from the 47 women who remainedo normocalcaemic ( $p=0.004$; Fisher's exact test). All 22 tumours from patients with serum calcium concentra tions $>2.9 \mathrm{mmol} / \mathrm{l}$ showed positive staining for para thyroid hormone related protein, while the three with negative staining were from patients with lower serung calcium concentrations $(2 \cdot 7,2 \cdot 7$, and $2 \cdot 9 \mathrm{mmol} / \mathrm{l})$.

Parathyroid hormone related protein $1-86$ was detectable in the plasma in five of 57 patients $(9 \%)$ with early breast cancer without known metastases (mean $0.33 \mathrm{pmol} / \mathrm{l}$; range $0.25-0.46 \mathrm{pmol} / \mathrm{l}$ ) and in $10 \mathrm{o}$ 28 patients $(36 \%)$ with bone metastases (mean $0.5 \%$ $\mathrm{pmol} / \mathrm{l}$; range $0 \cdot 23-1 \cdot 50 \mathrm{pmol} / \mathrm{l})$. In nine of this second group of patients with detectable parathyroid hormone related protein in whom parathyroid hormone $1-8 \dot{4}$ concentrations were measured the mean concentration was 23 (range 8-32) ng/l. Plasma parathyroid hormonê related protein 1-86 was detectable in 12 of $13(92 \%$ patients (mean $3.7 \mathrm{pmol} / 1$; range $0.54-8 \cdot 1 \mathrm{pmol} / 1$ ) with hypercalcaemia and in significantly higher concentran tions than in patients with early breast cancer $(p<0.01$ ? or in normocalcaemic patients with bone metastases ( $p<0.001$; Mann-Whitney U test) (fig 2). Plasma parathyroid hormone $1-84$ concentrations wer: measured in nine hypercalcaemic patients and were $<\xi$ $\mathrm{ng} / \mathrm{l}$ in four; the remaining five had a mean concentra< tion of 11 (range .7-17) $\mathrm{ng} / \mathrm{l}$. Positive immunostaining was found in all five tumours examined from womet with hypercalcaemia and increased plasma parathyroid hormone related protein 1-86 concentrations.

\section{Discussion}

This systematic study of tissue and plasma para thyroid hormone related protein in women with breas cancer and hypercalcaemia has shown a clear gradatio in the frequency of positive cytoplasmic staining fo parathyroid hormone related protein in breast cancer the lowest frequency being in tumours without associated metastatic disease and the highest in tumours associated with hypercalcaemia and bone metastases. 


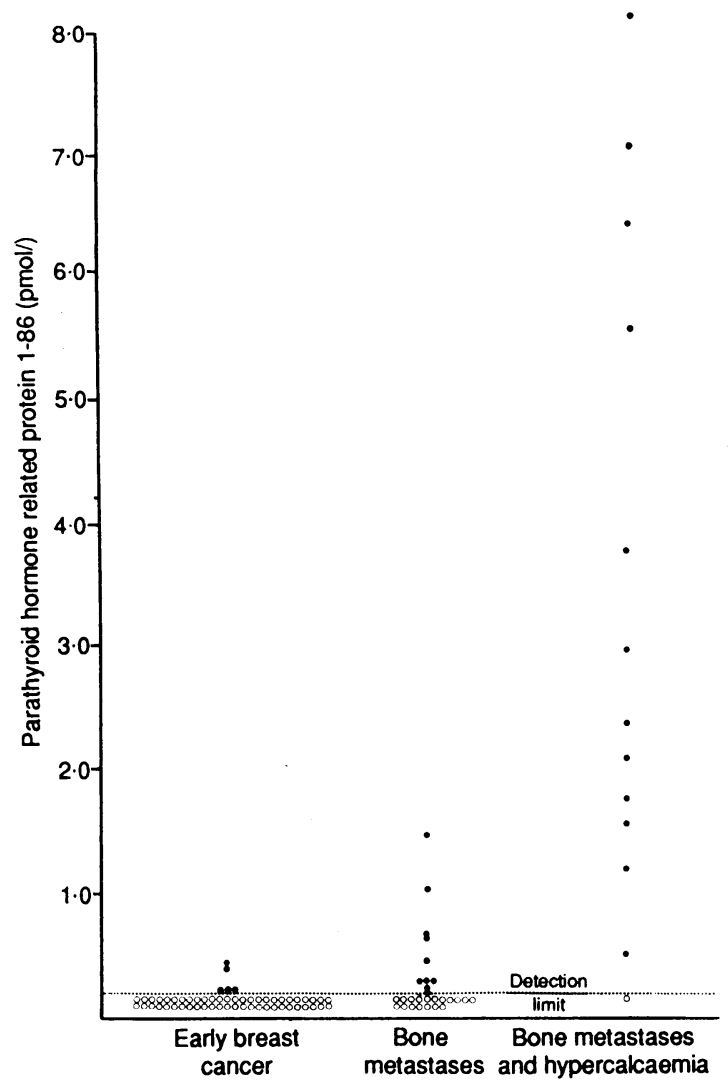

FIG 2-Plasma parathyroid hormone related protein 1-86 concentrations (two site immunoradiometric assay) in 57 women with early breast cancer, 28 women with disease recurrence in bone, and 13 women with bone metastases and hypercalcaemia. Open circles represent women in whom concentrations were undetectable

Importantly, there was a similar gradation in plasma parathyroid hormone related protein 1-86 concentrations measured with a validated two site assay. Thus plasma parathyroid hormone related protein 1-86 immunoreactivity was detected in $9 \%$ of normocalcaemic patients $(5 / 57)$ without apparent metastatic disease and in $36 \%$ of patients (10/28) with recurrent disease in bone. However, parathyroid hormone related protein concentrations were generally near the limit of detection of the assay in these groups and lower than we have found in patients with cancer associated hypercalcaemia. ${ }^{9}$ Furthermore, parathyroid hormone 1-84 concentrations were essentially normal in the patients with bone metastases and detectable concentrations of parathyroid hormone related protein, suggesting that the parathyroid hormone related protein concentrations were insufficient to override the mechanisms controlling calcium homoeostasis. In patients with hypercalcaemia plasma parathyroid hormone related protein 1-86 concentrations were increased in $92 \%$ of cases (12/13) compared with $40-50 \%$ of cases reported with less sensitive and discriminating methods, ${ }^{10-12}$ but concentrations were not as high as in patients with hypercalcaemia associated with solid tumours other than breast cancer. ${ }^{9}$

Although these findings are consistent with humoral parathyroid hormone related protein as a mediator of hypercalcaemia in breast cancer, they do not exclude the possibility that tumour derived bone resorbing factors (including parathyroid hormone related protein) may also act locally in bone or that interactions may occur between factors which individually may have only weak hypercalcaemic activity. ${ }^{13}$ Increased production of parathyroid hormone related protein by tumour tissue may be responsible for tamoxifen induced hypercalcaemia associated with the phenomenon of tamoxifen flare..$^{14}$

The finding of parathyroid hormone related protein immunostaining in almost all breast cancers associated with hypercalcaemia provides strong evidence that tumour synthesis is the likely source of the raised circulating concentrations. However, not all positively staining tumours were associated with hypercalcaemia, confirming other reports. ${ }^{15} 16$ This may reflect a low level of parathyroid hormone related protein secretion by the tumour, insufficient to overcome the homoeostatic control of serum calcium, or a low tumour burden. ${ }^{17}$ In addition, the development of hypercalcaemia may depend on the rate of clearance or metabolism of bioactive parathyroid hormone related protein, as impaired liver function associated with liver metastases is important in the development of hypercalcaemia in patients with breast cancer. ${ }^{18}$

As we used an antiserum to the mid-region of parathyroid hormone related protein our results complement a recent study which used an antiserum of amino terminal specificity. ${ }^{19}$ Both studies found positive staining in $50-60 \%$ of breast cancers, and an intriguing finding was that breast cancers which expressed parathyroid hormone related protein were more likely to recur in the skeleton. The higher parathyroid hormone related protein positivity reported in breast cancer metastases in bone than in non-bone sites is consistent with this finding..$^{20}$ The preferential recurrence of tumours positive for parathyroid hormone related protein that occur in bone suggests that the production of parathyroid hormone related protein may act locally to enhance the survival of tumour cells in bone or promote their ability to invade bone. As most patients develop metastases when plasma parathyroid hormone related protein concentrations are undetectable with the assay used here we have no evidence that circulating parathyroid hormone related protein is related to tumour recurrence. For prognostic and therapeutic purposes it will be important to determine whether tumour parathyroid hormone related protein positivity or absolute tissue concentrations, or both, can be used to provide useful markers to predict the pattern of relapse. ${ }^{21}$

We conclude that circulating tumour derived parathyroid hormone related protein is probably an important mediator of hypercalcaemia in patients with breast cancer and suggest that humoral mechanisms may have a more important role in hypercalcaemia associated with metastatic disease than has previously been recognised.

We thank Ms S Hughes for technical help with the parathyroid hormone related protein assays, $\mathrm{Mrs} \mathrm{C}$ Haywood for preparing the paraffin sections, Ms G Ubhi for secretarial work, Mr Roger Holder for statistical advice, the department of pathology at Selly Oak Hospital for routine histological reports, and the Department of Health for financial support.

Mundy GR, Ibbotson KJ, D’Souza SM, Simpson EL, Jacobs JW, Martin TJ The hypercalcemia of cancer: clinical implications and pathogenic mechanisms. N Engl F Med 1984;310:1718-26.

2 Mundy GR. Hypercalcemia of malignancy revisited. 7 Clin Invest 1988;82:1-6.

3 Gallacher SJ, Fraser WD, Patel U, Logue FC, Soukop M, Boyle IT, et al. Breast cancer-associated hypercalcaemia: a reassessment of renal calcium and phosphate handling. Ann Clin Biochem 1990;27:551-6.

4 Isales C, Carcangiu ML, Stewart AF. Hypercalcemia in breast cancerreassessment of the mechanism. Am $\mathcal{F}$ Med 1987;82:1143-7.

5 Percival RC Yates AJP, Gray RES, Galloway J, Rogers K, Neal FE, et al. Mechanisms of Alignant hypercalcaemia in carcinoma of the breast $B M f$ Mechanisms of

6 Suva LJ, Winslow GA, Wettenhall REH, Hammonds RG, Moseley JM Diefenbach-Jagger HD, et al. A parathyroid hormone-related protei implicated in malignant hypercalcemia: cloning and expression. Science implicated in malis

7 Martin TJ, Suva LJ. Parathyroid hormone-related protein in hypercalcaemi of malignancy. Clin Endocrinol 1989;31:631-47.

8 Martin TJ. Properties of parathyroid hormone-related protein and its role in malignant hypercalcaemia. $Q \mathcal{F}$ Med 1990;76:771-86.

9 Ratcliffe WA, Norbury S, Heath DA, Ratcliffe JG. Development and validation of an immunoradiometric assay for parathyrin-related protein in unextracted plasma. Clin Chem 1991;37:678-85.

10 Burtis WJ, Brady TG, Orloff JJ, Ersbak JB, Warrell RP, Olson BR, et al. Immunochemical characterisation of circulating parathyroid hormonerelated protein in patients with humoral hypercalcemia of cancer. NEngl f Med 1990;322:1106-12.

11 Henderson JE, Shustik C, Kremer R, Rabbani SA, Hendy GN, Goltzman D. 
Circulating concentrations of parathyroid hormone-like peptide in malignancy and hyperparathyroidism. F Bone Miner Res 1990;5:105-13.

12 Budayr AA, Nissenson RA, Klein RF, Pun KK, Clark OH, Dinh Diep BS, et al. Increased serum levels of a parathyroid hormone-like protein in et al. Increased serum levels of a parathyroid hormone-like protein

13 Sato K, Fujii Y, Kasono K, Tsushima T, Shizume K. Production of interleukin- $1 \alpha$ and a parathyroid hormone-like factor by a squamous cell carcinoma of the esophagus (EC-Gl) derived from a patient with hypercalcemia. F Clin Endocrinol Metab 1988;67:592-601.

14 Legha SS, Powell K, Buzdar AU, Blumenschein GR. Tamoxifen-induced hypercalcemia in breast cancer. Cancer 1981;47:2803-6.

15 Danks JA, Ebeling PR, Hayman J, Chou ST, Moseley J, Dunlop J, et al. Parathyroid hormone-related protein: immunohistochemical localisation in cancers and in normal skin. $\mathcal{F}$ Bone Miner Res 1989;4:273-8.

16 Kramer S, Reynolds FH, Castillo M, Valenzuela DM, Thorikay M, Sorvillo $J M$. Immunological identification and distribution of parathyroid hormonelike protein polypeptides in normal and malignant tissues. Endocrinolog 1991;128:1927-37.

17 Ralston SH, Danks JA, Hayman J, Fraser WD, Stewart CS, Martin TJ.
Parathyroid hormone-related protein of malignancy: immunohistochemical and biochemical studies in normocalcaemic and hypercalcaemic patients with cancer. I Clin Pathol 1991;44:472-6.

18 Coleman RE, Fogelman I, Rubens RD. Hypercalcaemia and breast cancer, an increased humoral component in patients with liver metastases. Eur F. Surg Oncol 1988;14:423-8.

19 Southby J, Kissin MW, Danks JA, Hayman JA, Moseley JM, Henderson MA, et al. Immunohistochemical localisation of parathyroid hormone-related protein in human breast cancer. Cancer Res 1990;50:7710-6.

20 Powell GJ, Southby J, Danks JA, Stillwell RG, Hayman JA, Henderson MA, et al. Localisation of parathyroid hormone-related protein in breast cancer metastases: increased incidence in bone compared with other sites. Cancer Res 1991;51:3059-61.

21 Van Holten-Verzantvoort A Th, Bijvoet OLM, Cleton FJ, Hermans J, Kroon HM, Harinck HIJ, et al. Reduced morbidity from skeletal metastases in breast cancer patients during long-term bisphosphonate (APD) treatment. Lancet 1987;ii:983-5.

\title{
Injuries from antipersonnel mines: the experience of the International Committee of the Red Cross
}

\author{
Robin M Coupland, Adriaan Korver
}

Medical Division,

International Committee of the Red Cross, CH1202

Geneva, Switzerland

Robin M Coupland, FRCS, surgeon

Adriaan Korver, MD, medical coordinator

Correspondence to: Mr Coupland.

BMf 1991;303:1509-12

FIG 1-(a) Traumatic amputation of left foot and lower leg caused by $\mid(b)$ buried antipersonnel mine

Design-Retrospective analysis.

Setting-Two hospitals for patients injured in war.

Subjects -757 patients with injuries from antipersonnel mines.

Main outcome measures-Distribution and number of injuries; number of blood transfusions; number of operations; disability.

Results - Pattern 1 injury results from standing on a buried mine. These patients usually sustain traumatic amputation of the foot or leg; they use

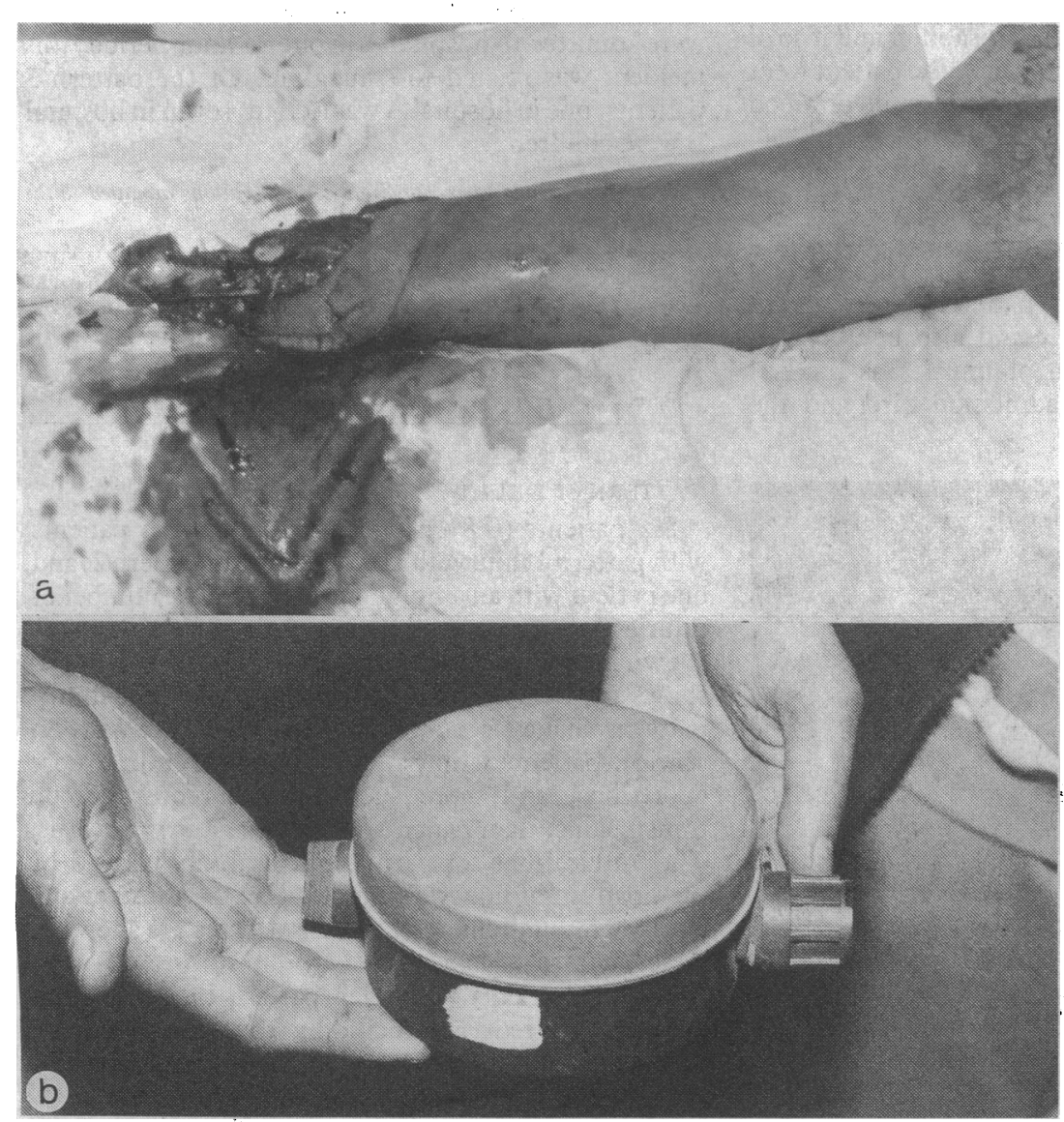

most surgical time and blood and invariably require

Objective-To describe and quantify patterns of injury from antipersonnel mines in terms of distribution of injury, drain on surgical resources, and residual disability.

BMJ VOLUME 303

14 DECEMBER 1991 surgical amputation of one or both lower limbs. Pattern 2 injury is a more random collection of penetrating injuries caused by multiple fragments from a mine triggered near the victim. The lower limb is injured but there is less chance of traumatic amputation or subsequent surgical amputation. Injuries to the head, neck, chest, or abdomen are common. Pattern 3 injury results from handling a mine: the victim sustains severe upper limb injuries with associated face injuries. Eye injuries are common in all groups.

Conclusions-Patients who survive standing on a buried mine have greatest disability. Non-combatants are at risk from these weapons; in developing countries their social and economic prospects after recovery from amputation are poor.

\section{Introduction}

The International Committee of the Red Cross (ICRC) deploys surgical teams for treating victims of war in 13 hospitals in Asia and Africa; these are served by first aid posts near the conflict areas. The teams are recruited from national Red Cross societies for three or six months of service.

Mine warfare is commonly used in developing countries, and antipersonnel mines may injure both combatants and non-combatants during and after a conflict. Surprisingly little attention has been paid to this subject in the medical literature; the medical implications of injury patterns and their severity have not been described.

This study was undertaken after the observation that victims of antipersonnel mines present with recognisable patterns of injury. Each pattern carries its own implication for the surgeon, the blood transfusion service, and patients' long term disability.

Three recognisable patterns of injury are seen in ICRC hospitals. In pattern 1 injury the victims trigger a buried mine by standing on the device. They usually have traumatic amputation of part of the lower limb $b^{1-3}$ with less severe injuries elsewhere; earth and the remains of the foot are blown upwards. Such mines may consist of explosive only or include fragments of metal or plastic. Many are specifically designed to incapacitate by traumatic amputation of all or part of the foot (fig 1). Pattern 2 injury results from a fragment mine being triggered. The pattern of wounding is more random, consisting of multiple fragment wounds (fig 2). Such mines may resemble a grenade and be 